\title{
Scolytus rugulosus (Muller) (Coleoptera, Scolytidae)-A New Pest of Acer undulatum Pojark in Turkey
}

\author{
Hamit Ayberk and Huseyin Cebeci \\ Department of Forest Entomology and Protection, Faculty of Forestry, \\ Istanbul University, 34473 Bahcekoy, Sariyer, Istanbul, Turkey
}

\begin{abstract}
Scolytus rugulosus (Muller), Shothole borer was detected as a new pest of Acer undulatum Pojark with this study. A. undulatum is a species of maple, endemic to Babadag near Fethiye in Mugla Province, southwest Turkey where it grows at altitudes of between 1400 and $1800 \mathrm{~m}$. The related pest is feeding and tunnelling between bark and cambium of mostly ornamental trees. The objective of the study was to determine the harmful pests threatening this endemic plant.
\end{abstract}

Key words: Acer undulatum, Scolytus rugulosus, first record, Babadag, maple, tunnelling

\section{INTRODUCTION}

Acer undulatum Pojark is a small, usually slow growing native tree endemic to Turkey, growing just only in Babadag region of Mugla province. It extends at altitudes of between 1400 and $1800 \mathrm{~m}$ and mostly present on western aspects and precipitous slopes (Fig. 1). Branches of this maple species are very shortly pubescent at first becoming grey brown and glabrous in the 2nd year, grey bark in later. Mature leaves are glaucescent, shining above and completely glabrous, dull beneath with 3-5 elevated veins, pubescent at base (Davis et al., 1988). Guner has reported that it is near to extinction and involved in IUCN Red List of near threatened species.

Scolytus rugulosus (Muller) was previously recorded on Acer platanoides, Crataegus sp., Cydonia sp., Malus sp., Prumus sp., Pyrus sp., Sorbus sp., Tilia sp. in Adana, Amasya, Ankara, Antalya, Balikesir, Bursa, Denizli, Istanbul, Izmir, Kahramanmaras, Malatya, Manisa,
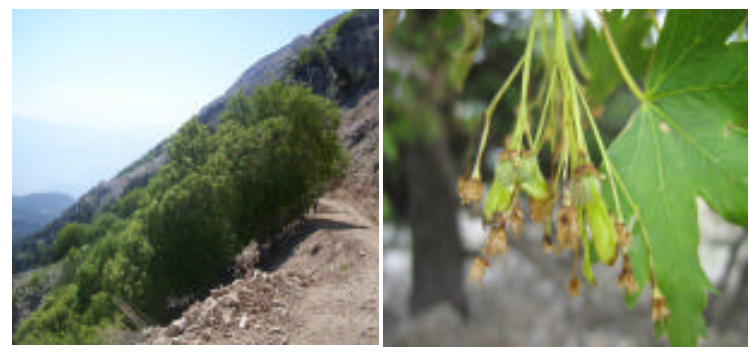

Fig. 1: Acer undulatum Pojark
Mersin, Nigde, Osmaniye and Trabzon (Alkan, 1964; Iren, 1977; Ulusoy et al., 1999). There is no any knowledge in the literature concerning damage of S. rugulosus on forest trees except Schedl.

But these bark beetles are living commonly in orchards on ornamental trees and that was recorded in many studies. The damage of $S$. rugulosus in FethiyeBabadag on this endemic and under extinction plant makes the research more important.

\section{MATERIALS AND METHODS}

The data were collected in the Mount of Babadag between the years of 2008 and 2009. Damaged trunks of Acer undulatum were cut off in the field and brought to the laboratory from May to September and reared in cages under natural conditions.

The emerging adults from the trunks and the main and larval galleries were examined carefully. The identification of the beetle were made using Leica 8.35 Stereozoom Microscope. For the identification process help also received from the experts.

The pest is a small, black beetle from $3.3-4.3 \mathrm{~mm}$ in length with the body quite blunt. Elytra are reddish brown with dark spots and dark medial band. Males have flat frons including dense short setae. On the other hand, females have round frons including sparsely distributed setae (Fig. 2). The adults and larvae of the beetle damage on the cambium. They are feeding and tunnelling between the bark and the cambium (Fig. 3).

Corresponding Author: Hamit Ayberk, Department of Forest Entomology and Protection, Faculty of Forestry, Istanbul University, 34473 Bahcekoy, Sariyer, Istanbul, Turkey 


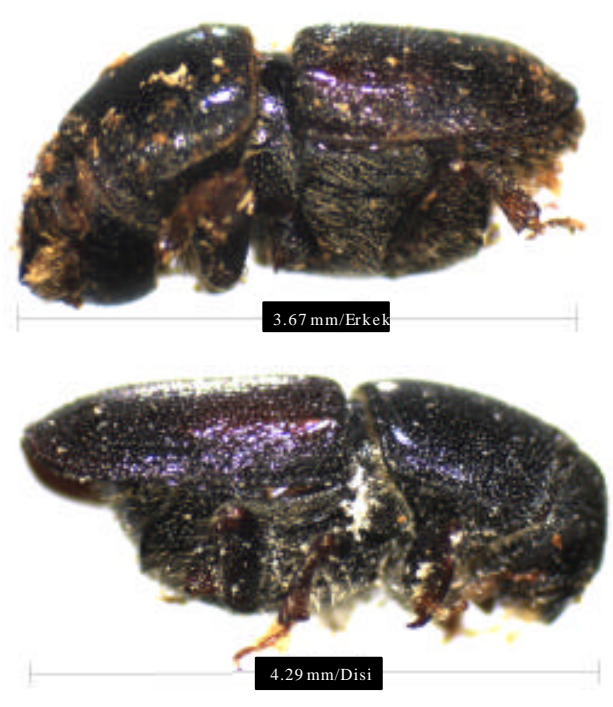

Fig. 2: Scolytus rugulosus (Muller)

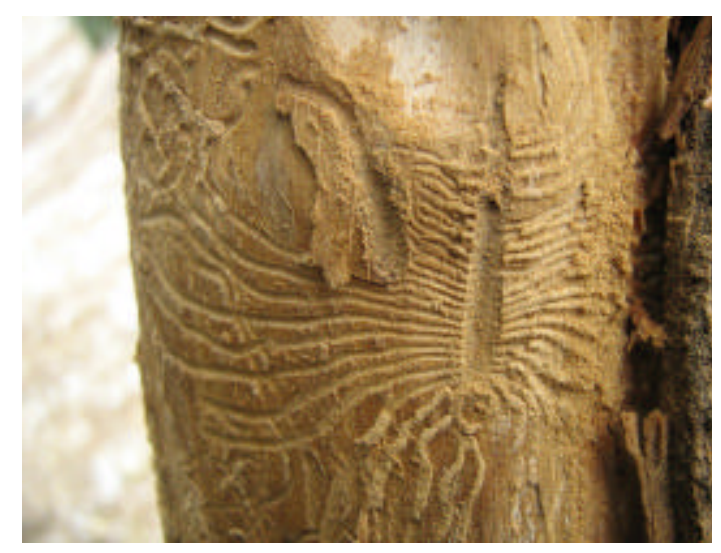

Fig. 3: The main and larval galleries

\section{RESULTS AND DISCUSSION}

Material examined: 18-05-2008 (in larvalstage), 24-06-2008 (in mature larval and pupation stage), 14-07-2008 (in adult stage), 20-08-2008 (in adult stage), 09-09-2008 (in adult and larval stage). 13-05-2009 (in larval stage), 24-06- 2009 (in mature larval and pupation stage), 15-07-2009 (in adult stage), 20-08-2009 (in adult stage), 11-09-2009 (in adult and larval stage). The total number of beetles collected from damaged trees was as follows: 127 (14-07-2008), 142 (20-08-2009) and 15 (11-09-2009).

The field and laboratory observations show us that S. rugulosus has one generation in a year in Babadag which region whereas according to Ulusoy et al. (1999); the related pest has generally two generations in a year at the entire life cycle in Turkey. In the observations the larvae both in the field and in the cages completed their growth, transformed to pupae and emerged as adults in the same year.

This data conflict with the reported literature. It is thought that there appears to be only one successful generation in a year because of the high elevation (1400-1800 $\mathrm{m}$ ) and the short vegetation period in the region. Low elevated localities have more favoured seasonal conditions and pest can do short second generation.

Schedl has reported in his study this pest attacked a number of indigenous or introduced fruit trees, besides damaging to Acer platanoides and Tilia sp. in Turkey. Thus its presence in A. undulatum is a new finding. Attacks were often observed after wounding of trees caused by logging activities or some climatic events such as frost, storm and lightning.

It is clear from experience gained in the infestations on fruit trees that population can raise to a high and damaging level. The most effective way to control shothole borer infestations in this endemic species is through good sanitation practices.

\section{ACKNOWLEDGEMENT}

The researchers wish to express their cordial thanks to Prof. Dr. Erdal Selmi for the identification of this bark beetle.

\section{REFERENCES}

Alkan, B., 1964. Studies about bark beetles (Col., Scolytoidae) damaging on plants in Turkey. Rev. Univ. Ankara, 14: 345-401.

Davis, P.H., K. Tan and R.R. Mill, 1988. Flora of Turkey and the Aegean Islands. Vol. 10, Edinburgh University Press, Edinburgh, pp: 590.

Iren, Z., 1977. Identifications, Damages and Biology of Important Orchard Pests and Control Methods. Plant Protection Chemicals and Equipment Institute Technical Books, Moscow, pp: 167.

Ulusoy, M.R., G. Vatansever and N. Uygun, 1999. The cherry pest, their natural enemies and observations on some important species in Ulukisla (Nigde) and Pozanti (Adana) province of Turkey. Turkish J. Entomol., 23: 111-120. 